\title{
Tampon Dosage Form
}

National Cancer Institute

\section{Source}

National Cancer Institute. Tampon Dosage Form. NCI Thesaurus. Code C47892.

A solid composed of a plug made from absorbent material. 